\title{
Norske straffedommer 1957
}

\section{Av høyesterettsdommer TRYGVE LEIVESTAD.}

\section{Sikring.}

En gift skogsarbeider på ca. 50 år hadde i løpet av en sommer hatt utuktig omgjengelse og foretatt utuktig handling med 3 småpiker i 9 årsalderen ved 6 forskjellige anledninger. Han ble d $\phi \mathrm{mt}$ til fengsel i 3 år og 1 mnd. og underkastet sikring for inntil 5 år. Domfelte var tidligere ustraffet, og anket for å få straffen betinget. Han hadde sittet 217 dager i varetekt da saken kom opp i Hr. Denne fant at det ville bli en utilstrekkelig reaksjon om reststraffen skulle gjøres betinget, og da det ikke er adgang til å gjøre en del av den betinget, måtte den bli ubetinget. Men $\mathrm{Hr}$. sluttet seg til lagmannsrettens anbefaling av at en del av straffen ble gjort betinget ved benådning, og pekte også på departementets adgang til å la straffen helt eller delvis falle bort ved overf $\varnothing$ ring til sikring. Domfelte var lite intelligent, og hadde vist tegn til sinnsforandring. Rt. s. 118.

En gift trelasthandler på 55 år, som tidligere var straffet med 2 års fengsel for landssvik, hadde sommeren 1954 ved to høve tatt med seg, en gang en pike på 13 år, og en annen gang en pike på 14 år, ombord i sin motorbåt, og der hatt utuktig omgjengelse med dem. Forholdet ble f $\phi$ rst anmeldt h $\phi$ sten 1955, og saken ble ikke påd $\phi \mathrm{mt}$ f $\phi \mathrm{r}$ november 1956. Dommen lød på fengsel i 3 år og 1 mnd. og sikring i 5 år. De sakkyndige hadde funnet at tiltalte hadde varig svekkede sjelsevner, og at det var fare for gjentagelse. De frarådet av medisinske grunner at tiltalte ble satt i fengsel. Hr. forkastet domfeltes anke for å få straffen gjort betinget; den lange tid som var gått, var ikke tilstrekkelig grunn til det når det gjaldt så graverende forbrytelser. Men $\mathrm{Hr}$. sluttet seg til uttalelsene om at domfelte ikke burde settes i fengsel, og pekte på adgangen for departementet til å la straffen helt eller delvis falle bort ved overføring til sikring. Rt. s. 155.

En tidligere straffet, fraskilt bygningsarbeider på 39 år hadde to ganger hatt utuktig omgjengelse med en gutt på 11 år. Han var nevrotiker, lå under for alkohol, og under rus kunne latente homoseksuelle anlegg komme fram. Han ble d $\varnothing \mathrm{mt}$ til fengsel i 3 år og 1 mnd. og sikring i 5 år. Hr. forkastet anke for å få straffen betinget, men uttalte at straffen p.g. av lovens minimum 3 år her ble urimelig $h \varnothing y$, og anbefalte at en del ble ettergitt ved benådning, eller ved overf $\varnothing$ ring til sikring. Rt. s. 899 .

En 44 år gammel byingeni $\phi \mathrm{r}$ ble d $\phi \mathrm{mt}$ for utuktige handlinger overfor 8 gutter i alderen $9-12$ år til fengsel i 1 år og 2 mnd. og sikring i 5 år. Tiltalte bodde helt alene, og hadde utenom sitt 
arbeid ingen omgang med voksne. Guttene pleide komme til ham og fikk frukt og godter, og undertiden større presanger. Iblandt klusset så tiltalte med kjønnslemmet på dem. Han hadde 3 år tidligere vært tiltalt for liknende forhold, men ble da frifunnet fordi bevisene sviktet. Lagretten svarte ja både på spørsmål om mangelfulle sjelsevner, fare for gjentagelse, og særdeles formildende omstendigheter. Tiltaltes psyke avvek sterkt fra det normale. Han manglet evne til kontakt med voksne, men var intelligent og hevdet et strengt moralsyn. Hans anke over straffeutmålingen ble forkastet, men Hr. pekte på adgangen for departementet til å la straffen falle bort ved overføring til sikring. (Denne adgang har departementet ikke brukt). Rt. s. 1133.

\section{Arbeidsskole.}

En ung gutt på 19 år hadde hatt en rekke betingede påtaleunnlatelser for tyveri, underslag, dokumentfalsk, biltyveri, m. v. Da han ikke overholdt de vilkår som var satt, ble han satt under tiltale og d $\phi \mathrm{mt}$ for tyveri, skadeverk og biltyveri til anbringelse i arbeidsskole. Rettens flertall mente han trengte oppdragende behandling. Han var vokset opp hos besteforeldrene som hadde skjemt ham bort, og han hadde vært en tid på Foldin skolehjem. Domfelte anket med tilslutning av sin verge. Han var $\mathrm{i}$ fast arbeid som sjåff $\varnothing \mathrm{r}, \mathrm{og}$ arbeidsgiveren ga ham en utmerket attest. Gutten var uvanlig flink og flittig, arbeidet $12-15$ timer i d $\phi$ gnet, behandlet bilen omhyggelig, og var helt pålitelig både ved behandlingen av bilene og de tildels store bel $\phi p$ han hentet. Han ville nå få $\sin 1 \phi \mathrm{nn}$ forh $\phi y$ et til kr. $200 \mathrm{pr}$. uke etter 6 mnd. tjeneste. - Etter dette fant Hr. i samsvar med påtalemyndigheten at det ikke var grunn til å anbringe gutten i arbeidsskole. Han fikk istedet 6 mnd. fengsel betinget. Rt. s. 897 .

\section{Betinget dom.}

En ung gutt som var pr $\varnothing$ vel $\varnothing$ slatt fra Berg arbeidsskole ble med en kamerat på brukstyveri av en bil, og kjørte den i påvirket tilstand. Han ble d $\phi \mathrm{mt}$ til fengsel i 30 dager ubetinget for dette forhold, mens en tidligere dom fortsatt ble stanende betinget $i$ to år. Rt. s. 213.

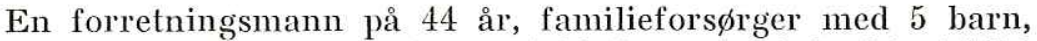
ble i forh $\phi$ rsrett d $\phi$ mt til fengsel i 30 dager for å ha kjørt bil i påvirket tilstand. $\mathrm{Hr}$. fant $\mathrm{i}$ strid med vanlig praksis å burde gjøre straffen betinget, men ga samtidig en ubetinget bot på kr. 500. Domfelte hadde en hjertelidelse, led av depresjoner, og misbrukte da alkohol. Han var nå under behandling for alkoholisme. To medisinsk sakkyndige mente at soning av fengselsstraff ville bety en skadelig psykisk belastning. Som særlig vilkår for å gjøre straffen betinget satte $\mathrm{Hr}$. at domfelte avholdt seg 
fra alkohol og underkastet seg slik kur som læge eller edruelighetsnemnd bestemte. Rt. s. 436 .

En 37 år gammel arbeider hadde vært straffet 4 ganger, i 1942 to ganger for tyveri, i 1946 for promillekjøring, og i 1950 for det samme og biltyveri. Sommeren 1956 fors $\varnothing$ kte han voldtekt overfor en ung pike idet han slepte henne bak uthusene ved hennes hjem, kastet henne overende, la seg over hende og fors $\phi$ kte å få klærne av henne. Han ble i lagmannsret dømt til fengsel i 3 år og 1 mnd. Med 3 mot 2 stemmer gjorde $\mathrm{Hr}$. straffen betinget. Flertallet la vekt på at straffeminimum 3 år virket urimelig h $\phi y t$. Det dreiet seg om fors $\phi k$, som $f \varnothing$ lge av en plutselig innskytelse under rus. Piken og hennes foreldre hadde trukket anmeldelsen tilbake. Domfelte hadde ikke tidligere gjort seg skyldig i sedelighetsforbrytelse, og hadde siden han giftet seg i 1950 iklke vært straffet. Han var flyttet til en annen bygd, var edruelig, hadde. fast arbeid og levet i gode familieforhold. Som særlig vilkår ble satt at domfelte måtte avholde seg fra alkohol i provetiden som ble satt til 3 år.

Mindretallet viste til at lagretten hadde svart nei på spфrsmål om særdeles formildende omstendigheter, og de tungtveiende generalpreventive hensyn. Selv om det kunne være enig i at minimumsstraffen var for $h \phi y$, burde det ikke lede til i realiteten full ettergivelse av straffen. Skadevirkningene for familien var her ikke andre enn de vanlige. Korrektivet mot at straffen ble strengere enn rimelig, måtte ligge i benådning. Rt. s. 458.

En 32 år gammel arbeider hadde vært straffet 1 gang for ran, og 2 ganger for grovt tyveri, siste gang i 1950. Han ble d $\varnothing \mathrm{mt}$ for tyveri fra 4 hytter han og en kamerat brot seg inn i, og tyveri av en forgasser, til fengsel i 120 dager. Under dissens gjorde $\mathrm{Hr}$. straffen betinget. Det ble lagt vekt på at de stjålne ting var av nokså liten verdi og for det meste kommet til rette, at tyveriene var leilighetspregede, og at domfelte hadde gått arbeidsledig i lengere tid da han begikk dem. Nå hadde han fått fast arbeid, og soning ville ramme også hustruen og barna hårdt. Rt. s. 541 .

En pensjonert sjømann på 68 år ble funnet skyldig i utuktig omgjengelse med 3 småpiker på 10 år, og blodskam overfor den ene av dem som var hans sønnedatter. Han hadde i sitt hjem 5-6 ganger tatt småpikene i skrittet, og fått dem til å onanere ham slik at han fikk sedavgang. På en av dem hadde han f $\varnothing \mathrm{rt}$ sitt kjønnslem opp i skrittet og foretatt samleiebevegelser. Straffen ble satt til fengsel i 3 år og 2 mnd. Lagmannsretten fant ikke å kunne gjøre straffen betinget. Domfelte hadde ellers levet et hederlig og uklanderlig liv. Han hadde avgitt full tilståelse. De psykiatrisk sakkyndige hadde ikke funnet tegn på svekkede sjelsevner. Lagmannsretten antok at det ville stride mot den alminnelige rettsbevisthet om det ble gitt betinget straff for så 
mange alvorlige forbrytelser, og at generalpreventive hensyn tilsa ubetinget straff.

To dommere i Hr. var enige i dette, selv om de mente at lovens minstestraff av fengsel i 3 år her ble urimelig streng, og pekte på at aktor henstilte til Hr. å anbefale at straffen i sin helhet ble gjort betinget ved benådning. Flertallet fant imidlertid å kunne gjøre straffen betinget. Det ble pekt på domfeltes tidligere gode vandel, og at de sakkyndige hadde uttalt at selve de handlinger som var begått, tydet på sjelelig svekkelse. Rt. s. 553.

En 36 år gammel fisker hadde vært dømt vesentlig for formuesforbrytelser 6 ganger, og vært ilagt bot vesentlig for fyll 9 ganger. Siste dom var fra 1954, og siste straff for tyveri var sonet i 1953. Han gjorde seg skyldig i 4 mindre tyverier sommeren 1956, og ble i byretten d $\varnothing \mathrm{mt}$ til fengsel i 1 år betinget med pr $\phi$ vetid 5 år og avhold og innmelding $i$ avholdslosje som særlig vilkår. Det var domsmennene som stemte for dette, idet rettsformannen stemte for 9 mnd. ubetinget. Hr. forkastet påtalemyndighetens anke. Det ble lagt vekt på at domfelte hadde holdt seg borte fra tyverier i 3 år, at tyveriene stod i sammenheng med drikk, at han nå hadde meldt seg inn $\mathrm{i}$ avholdslosje, og at sosialsjefen på hjemstedet og edruelighetsnemndas formann anbefalte betinget dom. Rt. s. 615.

En landhandler var kasserer for et veianlegg og underslo henved $20.000 \mathrm{kr}$. som han brukte til å dekke varegjeld. Han ble d $\varnothing \mathrm{mt}$ til fengsel i 6 mnd. som ble gjort betinget av at han i pr $\phi$ vetiden 2 år betalte det underslåtte bel $\phi$ p. Rt. s. 622 .

To unge menn på 24 år hadde vært $\mathrm{d} \phi \mathrm{mt}$ til arbeidsskole for tyverier, og var blitt pr $\phi$ veutskrevet $h \phi$ sten 1955 . Begge hadde tidligere vært straffed $\phi \mathrm{mt}$ for tyverier. De gjorde seg i prøvetiden skyldig i nye tyverier, den ene også i dokumentfalsk, og ble d $\phi \mathrm{mt}$ til fengsel, den ene i 1 år og 3 mnd. den annen i 8 mnd. Etter anbefaling av vernelag ble dommen gjort betinget med pr $\phi$ vetid 2 år. Begge var kommet $\mathrm{i}$ fast arbeid. Rt. s. 649.

En arbeider på 42 år gjorde seg skyldig i utuktig adferd overfor 2 piker under 16 år ved blottelser og us $\varnothing$ mmelig snakk, og foretok utuktig handling med et par piker under 14 år ved bef $\varnothing-$ ling og klemming. Domfelte var tidligere ustraffet; han var gift og hadde 2 barn. Han var medlem av bystyret og hadde flere tillitshverv. Straffen ble satt til fengsel i 1 år og 1 mnd. som ble gjort betinget. Rt. s. 725 .

En ung gutt på 24 år hadde i 1953 vært dømt for tyveri, og i 1954 d $\varnothing \mathrm{mt}$ til anbringelse i arbeidsskole for tyverier. Etter nesten 2 års opphold på arbeidsskolen ble han utskrevet. Under opphold på Kofoedskolen i Oslo for unge kriminalitetstruede, sovnet han fra en tendt sigarett med den følge at hans senget $\varnothing \mathrm{y}$ ble antendt, 
og skolens internat brennte ned. Han rømte fra stedet uten å delta i slukning eller forvisse seg om at de som bodde der ble vekket. Noen uker etter begikk han et tyveri. Like etter vendte han frivillig tilbake til Berg arbeidsskole. For uaktsom forvoldelse av brann med fare for utstrakt $\phi$ deleggelse og tap av menneskeliv, og tyveri ble han dømt til fengsel i 6 mnd. Hr. gjorde straffen betinget. Det ble lagt vekt på at domfelte nå hadde skikket seg bra, og at soning ville avbryte den utvikling han nå var inne i. Rt. s. 858.

En ung landhandler på 26 år hadde et par år vært assisterende kasserer i en liten bank. Han underslo ca. $48.000 \mathrm{kr}$. som han brukte i sin forretning. Under tvil og dissens, $3-2$, gjorde $\mathrm{Hr}$. straffen betinget. Det ble lagt vekt på at domfelte hadde avgitt uforbeholden tilståelse, ikke brukt penger til luksus e.l., og hadde betalt inn til banken, hvor han også hadde pantelån, et beløp større enn underslaget. Rt. s. 925 .

En 24 år gammel arbeider hadde 6 dommer fra tidligere, for beruselse, for legemsfornærmelse, for tyveri, for legemsbeskadigelse og for bilbrukstyveri og promillekjøring $\mathrm{m}$. v. 3 ganger hadde han vedtatt forelegg. Han gjorde seg påny skyldig i legemsbeskadigelse, idet han på en fest eglet seg inn på en mann og slo ham ned så han fikk hjernerystelse og en tids arbeidsudyktighet. Under dissens satte lagmannsretten straffen til fengsel i 120 dager betinget. Under dissens $3-2$ forkastet $\mathrm{Hr}$. anken. Det ble lagt vekt på at det syntes som domfelte hadde endret sin livsførsel, og at det var gått henved 2 år siden forbrytelsen. Rt. s. 1071.

En 40 år gammel fjøsrøkter med kone og 5 barn hadde 7 ganger vært d $\phi \mathrm{mt}$ for vinningsforbrytelser, siste gang i 1953 da han fikk fengsel i 6 mnd. for tyveri. Han stjal en motorkabel og 3 tepper til en samlet verdi av ca kr. 300 , og ble påny d $\phi \mathrm{mt}$ til fengsel i 6 mnd. Under dissens $3-2$ gjorde $\mathrm{Hr}$. straffen betinget. Flertallet la vekt på at det var gått nesten 2 år siden tyveriet, at han satt dårlig i det фkonomisk da han begikk sitt leilighetstyveri, og at boligen var betinget av at han utf $\phi$ rte fjøsarbeid, slik at soning ville ramme også familien meget hårdt. Mindretallet fant at det forelå slike særlige grunner at man kunne fravike den alminnelige regel om at betinget dom ikke gis den som har sonet fengselsstraff $\mathrm{i}$ de siste 5 år. Rt. s. 1225 .

\section{Brudd på vilkår for betinget dom.}

En arbeider på 50 år hadde tidligere fått to betingede dommer for tyveri. Dommene var ikke sonet. Han hadde ialt 12 forelegg for fyll o. 1. 11/4 1957 fikk han påny en betinget dom på fengsel i 120 dager. Som særlig vilkår var satt at han skulle betale rest- 
erstatning kr. 112, melde seg inn i avholdslag og avholde seg fra alkohol, og stå under tilsyn av vernelag. Allerede 12 og 22 dager etter dommen drakk domfelte seg påny beruset, og forh $\phi$ rsretten avsa så dom for at straffen skulle sones. Hr. fant imidlertid fortsatt å kunne la straffens fullbyrdelse utstå. Domfelte hadde nå meldt seg inn i avholdslag. Hans hustru var invalid etter en trafikkulykke, og sterkt åndelig redusert. For domfelte betød det et tap av støtte at hun ikke kunne gå med ham ut. Men han tok seg meget godt av henne og hun ville bli vanskelig stillet om han skulle sone. Domfelte var nå blitt medlem av avholdslag, og var villig til å underkaste seg avvenningskur. At han gjorde det, ble tatt inn i dommen som nytt vilkår. Rt. s. 802 .

En ung mann f. 1933 ble i august 1956 dømt for tyverier, heleri, dokumentfalsk og bedrageri til fengsel i 120 dager betinget. I januar 1957 fikk han betinget fengsel i 1 år for utuktig handling med barn. Han hadde tidligere hatt 5 påtaleunnlatelser for vinningsforbrytelser og i 1953 vært dømt til anbringelse på Berg arbeidsskole. Sommeren 1957 gjorde han seg påny skyldig i tyveri av en barbermaskin, og underslagg av ring og ur han lånte fra en pike. Han ble for disse forhold, og de to forhold han tidligere hadde fått betinget dom for, d $\phi \mathrm{mt}$ til en samlet ubetinget straff av fengsel i 8 mnd. Det ble uttalt at retten ved den nye dom foretok en ny og selvstendig straffeutmåling, og var derfor ikke bundet til å fastsette en ny straff strengere enn noen enkelt av de tidligere straffer. Rt. s. 1228.

\section{Vold mod politiet, strl. $\S 12 \%$.}

Vold mot politiet pleier av generalpreventive grunner å bli straffet med ubetinget fengsel. Det skal særlige omstendigheter til for at straffen skal kunne gjøres betinget.

Under rutinemessig kontroll ble en ung mann uten f $\varnothing$ rerkort, i lånt bil, stoppet av politiet. Istedenfor å stanse, satte han farten opp. En politimann hoppet opp på panseret på bilen, en annen åpnet bild $\phi$ ren. Tiltalte satte farten litt opp, så den ene politimannen falt av panseret. Den andre snublet og ble slept med

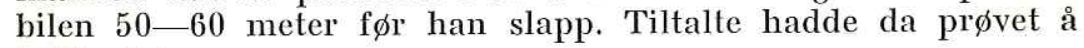
lukke døren.

Tiltalte ble dømt til fengsel i 60 dager for vold mot politiet, og for å ha kjørt uten f $\varnothing$ rerkort, og unnlatt å stanse for kontroll. Mot rettsformannens stemme gjorde domsmennene straffen betinget. Hr. forkastet påtalemyndighetens anke. Tiltalte var avholdsmann, hadde aldri f $\phi \mathrm{r}$ vært i konflikt med politiet, og var åpenbart grepet av panikk. Det var ikke grunn til å regne med noe festnet forbrytersk forsett. Rt. s. 452.

En 35 år gammel arbeider var i 1954 blitt dømt til fengsel i 120 dager for å ha slått ned en lensmannsbetjent og skadet ham 
på legeme. I mellomjulen 1955 drakk han seg full sammen med noen kamerater. Han sloss med dem, og lensmannen ble tilkalt. Tiltalte kastet jakken, truet lensmannen, og kastet ham overende og gned ham i фynene. Et par av kameratene fikk ham vekk, og tiltalte ble roligere. Litt etter fikk han et nytt raserianfall, og gikk løs på lensmannen påny og fikk ham overende. Andre kom til hjelp, og det ble skaffet håndjern og tau.

Tiltalte ble d $\phi \mathrm{mt}$ for vold og trusler, strl. $\S \S 127$ og 227, til fengsel i 8 mnd. med fradrag av 16 dager for varetekt. Straffen ble gjort betinget med prøvetid 3 år, og med særlig vilkår at tiltalte avholdt seg fra alkohol. Under dissens forkastet Hr. påtalemyndighetens anke. Det ble lagt vekt på at tiltalte hadde betalt kr. 1000 til den lensmannsbetjent han tidligere hadde skadet. Det var gått ca. 11/2 år siden forbrytelsen, og tiltalte hadde skikket seg vel i den tiden. Han hadde giftet seg f $\phi \mathrm{r}$ jul 1955, og hadde kone og barn å fors $\phi$ rge. Han hadde fast arbeid som han ville miste ved soning. Han var en dyktig arbeider, og hadde godt omd $\phi$ mme ellers. Den overfalte lensmannen gikk også sterkt inn for at tiltalte skulle slippe med betinget straff. Rt. s. 651 .

Forbrytelser mot sedelighet.

(Se også under avsnittene om sikring og betinget dom.)

En 57 år gammel maskinarbeider, gift og med en voksen s $\varnothing \mathrm{nn}$, hadde gjort seg skyldig i utuktig handling med barn under 14 år ved at han hadde tatt borti skrittet på 6 småpiker ved forskjellige anledninger; han hadde også blottet seg overfor en rekke småpiker. Pikene hadde bes $\phi$ kt ham på hans verksted, og etterhvert hadde det utviklet seg til seksuelt snakk og handlinger som barna også hadde vært med på. Domfelte var avholdsmann og aktivt medlem av stedets baptistmenighet, intellektuelt og følelsesmessig normalt utstyrt. Han ble d $\phi \mathrm{mt}$ til fengsel i 1 år og 1 mnd. Hr. gjorde straffen betinget, med prøvetid 2 år under tilsyn. Rt. s. 210.

En 30 år gammel mann med hustru og 1 barn hadde hatt et samleie med en pike på 13 år og 2 med en pike på 14-15. Lagretten svarte ja på et spørsmål om særdeles formildende omstendigheter. Straffen ble satt ned under lovens vanlige minimum på 3 år til fengsel i 1 år og 3 mnd. Retten fant at tiltaltes forhold gjorde fullbyrdelse n $\phi$ dvendig, selv om handlingene lå $2-3$ år tilbake i tid. Hr. forkastet domfeltes anke for å oppnå betinget dom. Rt. s. 695.

En tidligere stuert hadde giftet seg da han var i 50 årene, og flyttet til sin kone. Der ble han kjent med en familie som hadde et barnebarn, en småpike på 8-9 år som var nærmest blind. Piken vanket stadig hjemme hos tiltalte, og det ble etterhvert et seksuelt forhold, som førte til at de i et hvert fall fra piken var 
15 år ofte hadde samleie. Han ble dømt for dette til fengsel i 12 mnd. Han anket for å få straffen gjort betinget. Hr. forkastet dette, men satte straffen ned til fengsel i 8 mnd. Rt. s. 723.

En sjåff $\phi r$ på 23 år, med 3 barn, hadde samleie med en pike på $15 \frac{1}{2}$ år. Piken var blitt med ham på tur i bil, og hadde latt seg kysse, men ellers gitt uttrykk for at hun ikke ville ha med ham å gjøre. Hun var tidligere uberørt. Tiltalte ble dømt til lovens minimumsstraff, fengsel i 6 mnd. Hans anke for å få betinget dom ble forkastet av $\mathrm{Hr}$. med 4 mot 1 stemme. Rt. s. 776.

En 31 år gammel fjøsr $\phi k$ ter, med hustru og 4 barn fors $\phi k$ te voldtekt overfor en 15 års pike som han overfaldt en natt på en gårdsvei. Han slengte henne overende, truet med å drepe henne hvis hun gjorde motstand, prøvte å dra buksen av henne, og tok strupetak på henne da hun skrek. Piken ble i lengere tid nervøs og opprevet.

Domfelte var tidligere ustraffet. Han hadde handlet under sterk nedsettelse av bevistheten som følge av selvforskyldt rus. Lagretten svarte nei på spørsmål om særdeles formildende omstendigheter, men ja på spørgsmål om fare for gjentagelse av liknende straffbare handlinger. Domfelte ble derfor underkastet sikring for inntil 5 år. En dommer i lagmannsrett stemte for fengsel i $4 \frac{1}{2}$ år, mens de to andre stemte for fengsel i $3 \frac{1}{2}$ år. De fant ikke å kunne se bort fra at domfelte kunne ha en hjerneskade som kunne disponere for epileptiske utfall.

Under dissens satte Hr. straffen ned til fengsel i 2 år. Det ble lagt vekt på at domfelte $\mathrm{i}$ edru tilstand ikke hadde kriminelle tilb $\phi$ yeligheter. Man hadde ikke funnet patologiske trekk hos ham, men det var ting som tydet på at hans terskel for epileptiske manifestasjoner var nedsatt. Derfor var det fare for gjentagelse ved alkoholmisbruk. Muligheten for at en hjerneanomali hadde spilt inn, måtte komme domfelte til gode. Men det var ikke tilstrekkelig grunnlag for å gjøre straffen betinget. Hensynet til den alminnelige lovlydighet talte også mot det.

To dommere fant ikke tilstrekkelig grunn til å fravike lagmannsrettens skjønn, idet den hadde hatt vesentlig bedre grunnlag å bygge på. Rt. s. 976.

En gårdbruker på 65 år, enkemann, hadde i løpet av 1 års tid flere ganger utuktig omgjengelse, til dels samleie, med en pike på $12-13$ år. Han ble dømt til fengsel i 3 år og 1 mnd. Hans anke for å få betinget dom ble forkastet. Men $\mathrm{Hr}$. uttalte at da minimumsstraffen var høyere enn man ellers ville utmålt straffen, burde straffetiden nedsettes ved benådning. Rt. s. 1073.

En 24 år gammel sjåff $\varnothing r$ hadde samleie med en pike på 131/2 år, som ble besvangret. Han anket forgjeves for å få straffen på 3 år gjort betinget. Hr. uttalte at minimumsstraffen var for 
streng, og anbefalte nedsettelse ved benådning. Den er da også satt til 1 år og 6 mnd. Rt. s. 1158.

\section{Forbrytelse med hensyn til familieforhold.}

En 48 år gammel handelsreisende som var skilt og betalte bidrag til hustru og to barn som hun hadde fått foreldremyndigheten over ved dom, tok sin 9 årige $\operatorname{snn}$ med seg på en reise til Danmark, England og Irland i henved to måneder, uten at hustruen eller andre fikk noen underretning. Han ble dømt etter strl. § 217 for å ha undratt barn fra foreldres omsorg og myndighet ved å ta det med ut av landet til lovens minstestraff, fengsel i 2 år betinget. Ved samme dom ble han dømt til fengsel i 30 dager ubetinget for promillekjøring. Domfelte hadde sittet $\mathrm{i}$ varetekt i 53 dager for bortf $\varnothing$ relsen av s $\varnothing$ men, og fik fradrag i den betingede straff for det. Han anket forgjeves for å få utmålt en felles fengselsstraff som kumne være betinget for en del, og hvor varetektsarresten skulle gå fra $\mathrm{i}$ den ubetingede del. $\mathrm{Hr}$. fant ikke grunn til å gjøre noen endring, idet det ikke var urimelig at domfelte måtte sone for sin promillekjøring uten noe fradrag for en vaketekt som ikke hadde noe med den å gjøre. Rt. s. 755 .

\section{Forbrytelser mot liv, legeme og helbred.}

En 29 år gammel mann som tidligere hadde vært straffed $\phi m t$ 6 gangre, og var løslatt 3 mai 1956, stjal om kvellen 16 mai en seddelpung med 70 kroner i et begravelsesbyrå, og slo ned en 41 årig kvinne som overrasket ham, slo henne med en keramikvase som knustes, og kvalte henne med henderne for å undgå å oppdages. Domfelte hadde manglet sin mors omsorg under oppveksten fordi hun hadde hatt tuberkulose; fra 17 års alderen hadde han vært krigsdeltaker på tysk side. Han var betegnet som psykopat og nevrotiker. Han ble dømt til fengsel i 15 år, og sikring $\mathrm{i}$ inntil 10 år. Rt. s. 184.

En velstående gårdbruker f. 1897 hadde i 1935 kjøpt seg gård $i$ en annen bygd. Der begynte en handelsmann forretning i nabolaget. Det ble venskap og omgang mellom de to familier. I 1951 oppstod det et forhold mellom gårdbrukeren og handelsmannens hustru. Ektefellene fikk rede på det, og forholdet ble brutt. I 1954 ble det gijenopptatt, og partene bestemte seg for å bli skilt og gifte seg med hverandre. Etter formidling av en slektning skulle forholdet igjen være slutt, men ble så tatt opp igjen. I 1956 fik handelsmannens frue separasjon, og tok huspost i Oslo. Det drog ut med gårdbrukerens separasjon, p. g. av фkonomiske forhold og hensyn til et av hans 4 barn. Gårdbrukeren kjørte en dag i sin bil etter den fraskilte frue. Først var det misstemning mellom dem, fordi hun hevdet at han bare gjorde som konen sa. Så gikk det over, og partene hadde samleie ute. Litt etter ble det 
igjen misstemning, hun ga uttrykk for at han hadde bedratt henne og var skyld i det hele, og de kom i voldsomt sinne så hun fiket til ham. Det endte med at han kvalte henne med et belte. Etterpå varslet han lensmannen og kjørte med politiet til åstedet. Tiltalte var av normal intelligens, og fremb $\varnothing$ d ikke psykopatiske trekk. De sakkyndige fant under noen tvil at han p.g.av den voldsomme affekt han var kommet $i$, hadde hatt sterkt nedsatt bevisthet på handlingstiden. Lagretten svarte ja på spørsmål om særdeles formildende omstendigheter. Straffen ble satt til fengsel i 4 år.

Påtalemyndighetens anke ble forkastet av Hr. To dommere mente at det ikke var tilstrekkelig grunn til å gå under lovens vanlige minimumsstraff av 6 år. Rt. s. 206.

En sjømann på 52 år, skilt, 3 ganger straffed $\varnothing \mathrm{mt}$ for tyveri og sedelighetsforbrytelse for mange år siden, hadde gått sykmeldt vel ett år. Han br $\phi t$ seg en natt inn i et hus, oppholdt seg der noen timer, og kom inn i et værelse hvor en kvinne lå og sov. Da hun våknet, slo han henne ned med en rekke slag i hodet med en skrun $\varnothing k k e l$ så hun d $\varnothing$ de. Tiltalte hadde sterkt nedsatt bevisthet i gjernings $\phi$ yeblikket, idet han var beruset. Man måtte imidlertid regne med at bevisthetsnedsettelsen delvis kunne skyldes hjerneskader og/eller overdreven bruk av medikamenter. Antagelig hadde han brutt seg inn for å stjele eller $\phi$ ve voldtekt, uten at man kunne vite sikkert hva. Han ble dømt til fengsel i 10 år og sikring også i 10 år. Rt. s. 690 .

\section{AErekrenkelse.}

Med 13 mot 2 avgjorde Hr.s plenum i en sak som var omfattet med stor interesse i stortingskretser og blandt jurister at grunnlovens $\S 66$ er til hinder for at det kan reises s $\varnothing \mathrm{ksmål} \mathrm{mot} \mathrm{en}$ stortingsmann for uttalelser i Stortinget. Forholdet var at en representant under debatt i Stortinget hadde uttalt om en forretningsmann at han hengte ut kroker for departementet som det ikke burde bitt på, og at mannen kunne omgås ordene lettvint og sannheten kanskje enda lettvintere. Forretningsmannen anla mortifikasjonss $\varnothing \mathrm{ksmål,} \mathrm{og} \mathrm{fikk} \mathrm{i} \mathrm{byretten} \mathrm{medhold} \mathrm{under} \mathrm{dissens.}$ $\mathrm{Hr}$. opphevet dommen og avviste saken.

Avgjørelsen var forsåvidt oppsiktsvekkende, som en praktisk talt enstemmig teori hadde antatt at det var adgang til mortifikasjon, og at det bare var straff og erstatning som var utelukket. Gr.l. § 66 er ikke særlig klar når den uttaler om representantene at ,ei heller kunne de udenfor Stortingets Forsamlinger drages til Ansvar for deres der ytrede Meninger". På grunnlovens tid hadde man ikke rene mortifikasjonss $\varnothing$ ksmål. Men etter grunnlovens forbilder, særlig den amerikanske forfatning, og den praktiske betydning en mortifikasjonsdom har, fant flertallet det 
utvilsomt at frihet for ansvar også måtte innebære frihet for mortifikasjonss $\varnothing$ ksmål.

Mindretallet la vekt på behovet for beskyttelse av borgernes ære, og den praktisk talt samstemmige teori. Rt. s. 32 .

En gårdbruker skjøt et rådyr som gnaget på hans frukttrær. Han ble anmeldt for overtredelse av jaktloven. En kvinne forklarte seg til lensmannen om skytingen. Da gårdbrukeren ble kjent med hennes forklaring, pakket han 30 tiøringer i en bit av rådyrskinnet og sendte henne med en merkelapp påskrevet „Hermed 30 penger for vel utf $\varnothing$ rt arbeid. Jeg har først idag fått vite det". For dette ble han d $\varnothing \mathrm{mt}$ til bot kr. 150 - subsidiært fengsel i 12 dager.

Underslag og tyveri.

(Se også under avsnittet betinget dom.)

To sjåff $\phi$ rer og en hjelpearbeider, alle tidligere ustraffet hadde stjålet kull fra det kullfirma de arbeidet for. Dels for egen regning, dels sammen med medskyldige, hadde sjåff $\varnothing$ rene hver solgt

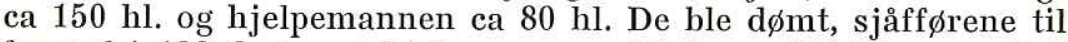
fengsel i 120 dager og hjelpemannen 90 dager. Sjåff $\phi r e n e$ anket forgjeves for å få betinget dom. Hr. uttalte at det måtte reageres strengt overfor bedriftstyverier. For hjelpemannen forelå særlige forhold, han var først kommet inn i bedriften da tyveriene var i full gang, så han fikk straffen gjort betinget. Rt. s. 646 .

En mann på 32 ble ansatt som disponent for en trelastforretning. I løpet av vel et år underslo han ca kr. 240.000 som han dels brukte til dekning av privat gjeld, dels overf $\phi r t e ~ t i l$ en bedrift han selv eiet. Han ble d $\varnothing \mathrm{mt}$ til fengsel i 2 år, og anket forgjeves for å få straffen nedsatt eller gjort betinget. Rt. s. 449 .

En tømmermann på 33 år som for 5 år siden hadde sonet en dom for formuesforbrytelser, og hadde adskillige b $\varnothing$ ter for beruselse, hadde gjort seg skyldig i en rekke hyttetyverier på en $\phi y$ i Oslofjorden. Han fikk fengsel i $1 \frac{1 / 2}{2}$ år i forhørsrett. Hr, var enig $i$ at det måtte reageres strengt mot den slags tyverier, men satte straffen ned til fengsel i 1 år. Rt. s. 1255 .

\section{Bedrageri.}

En frakteskudereder fikk skutef $\phi$ rerne til å senke 3 fart $\phi y e r$ for å få forsikringssummene. Han avga falsk forklaring bekreftet med forsikring på ære og samvittighet under sjøforklaring, fortiet at løsøre var berget, og han påvirket et mannskap til å gi falsk forklaring. Rederen fikk fengsel i $2 \frac{1}{2}$ år, og to f $\phi$ rere som hadde senket sitt fartøy og gitt falsk forklaring fikk fengsel i 10 mnd. Et mannskap som hadde gitt falsk rettslig forklaring bekreftet med ed om et forlis slapp med lovens minstestraff fengsel i 6 mnd, betinget. Rt. s. 56 . 
En agent var gått konkurs. Han opplyste til bostyret at en varebil han hadde tilh $\phi$ rte en annen, for å unnga at den ble trukket inn i bomassen. Han solgte den for vel kr. 5500 til en annen mann, idet han fortiet at bilen tilh $\phi$ rte boet. Lagmannsretten d $\varnothing \mathrm{mte}$ ham for konkursforbrytelse ( $\S 281$, 1. ledd) og bedrageri $(\S 270)$ til fengsel i 5 mnd. ubetinget. Den la vekt på at tiltalte tidligere hadde vært dømt, siste gang i 1952 for underslag og falsk forklaring til fengsel i 45 dager. Hr. fant å kunne gjøre dommen betinget. Domfeltes tidligere forgåelser lå langt tilbake i tid. Han hadde ligget under for drikk, men hadde nå underkastet seg en lengere kur og var blitt avholdsmann. Han var kommet igang med ny forretning, og soning ville gjøre det vanskelig å holde den gående, og ramme hustru og 3 barn han fors $\phi$ rget. Rt. s. 455.

\section{Skadeverk.}

En 21 år gammel sersjant i flyvåpnet som ikke hadde flyverutdannelse, tok et jetfly uten tillatelse, forledet vaktene ved uriktige opplysninger, og fl $\phi y$ med flyet ca. $3 / 4$ time. Ved landingen havarerte flyet og fikk skader for kr. 47.000. Han ble d $\varnothing \mathrm{mt}$ for grovt skadeverk og overtredelse av militær tjenesteplikt til fengsel i 6 mnd. som Hr. fant å kunne gjøre betinget. Domfelte var en ellers bra ung mann som ikke hadde vist kriminelle tilb $\phi$ yeligheter, og handlingen måtte ses som utslag av en flyverdrøm som var blitt en slik vrangforestilling hos ham at han ikke hadde normalt herred $\varnothing \mathrm{mme}$ over seg selv. Han ble d $\varnothing \mathrm{mt}$ til å erstatte skaden med kr. 47.000, men bare betaling av kr. 7000 med kr. $200 \mathrm{pr}$. mnd. ble gjort til vilkår for soningsutsettelsen. Rt. s. 818.

\section{Militær strafferett.}

En menig soldat hadde ikke unders $\phi k t$ at hans gevær var sikret f $\phi \mathrm{r}$ han foretok noen $\phi$ velser med det. Det gikk uventet av, og skuddet traff en annen i magen. Han ble alvorlig såret, fikk 9 ukers sykehusopphold og sandsynligvis noen varig invaliditet. Soldaten ble dømt for uforsiktig omgang med skytevåpen til fengsel i 30 dager som $\mathrm{Hr}$. av almenpreventive grunner og p. g. av den alvorlige følge gjorde ubetinget. Rt. s. 390 .

En sersjant gikk inn i en hangar for å tappe litt bensin av et fly for å rense trekket i sin bil. Han fikk vaktposten til å holde $\phi$ ye med at det ikke kom noen tilstede mens han gjorde det. Han ble $d \varnothing \mathrm{mt}$ for overtredelse av militær tjenesteplikt som befalingsmann til fengsel i 30 dager ubetinget. Rt. s. 440. 


\section{Alkoholloven.}

En 46 år gammel arbeider hadde en gang laget $1 \frac{1}{2}$ flaske brennevin, og gitt en flaske til en kamerat, og hadde laget $40 \mathrm{l}$. sats til en ny brenning. Han hadde året $\mathrm{f} \phi \mathrm{r}$ fått bot $\mathrm{kr}$. 300 for heimebrenning. Han ble d $\varnothing \mathrm{mt}$ til fengsel i 30 dager, som $\mathrm{Hr}$. under dissens, $3-3$, gjorde betinget, men med tillegg av en bot kr. 300 ubetinget. Rt. s. 322.

\section{Luftfart.}

En mann på 32 år, som hadde vært flytelegrafist, og var medlem av S.A.S. flyklubb, men ikke hadde flysertifikat, kom med en venn på Fornebu flyplass. Begge var påvirket av alkohol, domfelte nokså meget. Han fikk $\phi$ ye på et lite toseters fly, og fl $\phi y$ uten videre en tur med sin venn. Flygingen var ureglementert og uforsvarlig, så politi og ambulanse ble varslet. Ruteflyet måtte vente $10 \mathrm{~min}$. med sin landing $\mathrm{p}$. g. av domfeltes flyging. Han påførte sitt fly noen skade. Man har ingen bestemmelse som rammer „promilleflyging“ som forh $\phi$ rsretten uttalte var mer graverende enn „promillekjøring“. Domfete ble felt for flyging uten sertifikat og overtredelse av løsgjengerlovens $\S 17$ - forstyrrelse av den lovlige fred og orden, eller den alminnelige ferdsel eller forvoldelse av fare for andre i beruset tilstand - til fengsel i 90 dager. Rt. s. 693.

\section{Dyrevern.}

En forpakter hadde et par ganger av dyrevernsnemnda fått advarsel for sulteforing. Ved et tredje bes $\varnothing \mathrm{k}$ henstillet nemnda til ham å skille seg med alle sine dyr, 3 kuer, 1 hest og 6 griser. Forpakteren gikk med på det, men beholdt 5 griser. Ved et nytt bes $\phi k$ en tid senere fant man grisene ytterst utmagret. Sulteforingen skyltes manglende $\phi$ konomisk evne, idet forpakteren var uskikket som gårdbruker og klarte seg så dårlig $\phi$ konomisk at det gikk ut over dyrene. Han ble d $\varnothing \mathrm{mt}$ etter dyrevernloven for sulteforing til fengsel i 30 dager som ble gjort betinget, og for en tid av 5 år frad $\varnothing m t$ retten til å eie, ha og stelle kuer, hester, sauer og griser. Han anket over rettighetstapet, og under dissens, $3-2$, innskrenket $\mathrm{Hr}$. det til å eie og ha dyr, derimot ikke til å stelle dyr, idet det ville begrense hans muligheter for å livberge seg og familien ved å ta arbeid på nabogårder. Rt. s. 266. 